\title{
Note
}

\section{Post-lobectomy intrapulmonary metastasis of lung carcinoma in a dog treated with surgical resection and adjuvant chemotherapy.}

\author{
Takayuki Furukawa ${ }^{1)}$, Hajime Aoki ${ }^{2}$, Yutaka Fujii ${ }^{1)}, K_{a z u m i} \mathrm{Nibe}^{3)}$, Manabu Suzuki ${ }^{4)}$, Kenichiro Ono ${ }^{3)}$, \\ Hidehiro Hirao ${ }^{1,3)}$
}

\begin{abstract}
A 9-year-old neutered female Miniature Dachshund had undergone lobectomy of the left frontal lobe for lung carcinoma followed by nine post-operative doses of carboplatin chemotherapy $\left(250 \mathrm{mg} / \mathrm{m}^{2}\right.$, every 3 weeks). The dog was referred to the Japan Animal Referral Medical Center (Nagoya), because of lung masses in the opposite right middle and posterior lobes. Whole body contrast-enhanced computed tomography (CT) was performed and revealed lung solitary tumors in the relevant areas. No abnormal findings were observed in other lobes or intrathoracic lymph nodes. Since the possibility of metastatic lesions of lung carcinoma incompletely removed in the previous surgery was considered, we performed CT again on day 45 for evaluation of the new tumor progression. The size of both tumors increased, and right middle and posterior lung lobectomies were carried out on day 53. There were no adhesive lesions around the tumors, carcinomatous pleuritis, pleural fluid or hilar lymphadenopathy. While histopathology revealed high-grade lung adenocarcinoma with numerous mitoses, there was no evidence of intravascular invasion, suggesting complete resection. A tentative diagnosis of metastatic lung tumor (T2N0M1) was made. Adjuvant chemotherapy with carboplatin $\left(250 \mathrm{mg} / \mathrm{m}^{2}\right.$, for every 3 weeks $)$ and piroxicam $(0.3 \mathrm{mg} / \mathrm{kg} / 3 \mathrm{days})$ was also given starting on day 21 , and no evidence of recurrent lesions was observed on day 726 with a good health condition maintained.

From these results, it is suggested that aggressive surgery plus adjuvant chemotherapy can be appropriate treatments for metastatic lung carcinoma.
\end{abstract}

Key word : canine, chemotherapy, CT, lung carcinoma

1) Japan Animal Referral Medical Center Nagoya, 1-602 Konosu, Tenpaku-ku, Nagoya, Aichi 468-0003, Japan

2) Pet Clinic Aoki, 4-314 Hirako, Asada-cho, Nisshin-shi, Aichi 470-0124, Japan

3) Japan Animal Referral Medical Center Kawasaki, 2-5-8 Kuji, Takatsu-ku, Kawasaki-shi, Kanagawa 213-0032, Japan

4) Small Animal Pathology Service, 86-1 Hanare, Tsukuba-shi, Ibaraki 305-0857, Japan

Corresponding author : Takayuki Furukawa Telephone : 052-933-9901 Facsimile : 052-800-1213

Email address : takayuki.furukawa@jarmec.jp

Received : July 1, 2014 / Accepted : November 10, 2014 


\title{
肺葉切除後に肺内転移が認められた犬に対し 外科切除および補助的化学療法を行った 1 例
}

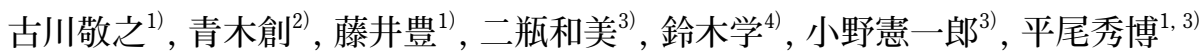

犬の原発性肺腫瘍の発生率は全腫瘍中 $1 \%$ とされ、約 $85 \%$ は気管支肺胞由来である。肺腫瘍は局所浸潤または血行性やリ ンパ行性に広がり、他の肺葉や胸腔内リンパ節への転移を起こす $[8]$ 。Griffey らは犬の悪性肺腫瘍の $71 \%$ には局所の脈管 内浸潤やリンパ管内浸潤が認められ、23\%に肺門リンパ節転移が認められると報告している $[2] 。$ 遠隔転移の認められな い原発性肺腫瘍に対する第一選択治療は外科切除である。原発性肺腫瘍に対し、術後の補助的化学療法としてビンデシン やビンデシンとシスプラチン併用、ドキソルビシン、ミトキサントロンまたはビノレルビンなどを使用し、ビノレルビン については気管支肺胞癌の犬の7頭中 2 頭で部分宽解が認められたとの報告がなされているが、いずれも症例数は少なく、 補助的化学療法の有効性について不明である。我々は肺内転移と考えられる肺腺癌 T2N0M1に対し、外科切除打よび術後 補助的化学療法を実施し、比較的長期間寛解期間を維持できているので報告する。

症例はミニチュア・ダックスフンド、避妊雌、9歳齢、体重 $4.3 \mathrm{~kg}$ である。既往歴として 9 ヶ月前に発咳を主訴に紹介病 院を受診し、左前葉前部に腫瘤が認められ左前葉前部切除を行い、病理組織学的検查結果は肺腺癌、進行度はWHO の TNM 分類に基づき T1N0M0 と診断された。術後補助的化学療法としてカルボプラチン $250 \mathrm{mg} / \mathrm{m}^{2} を 3$ 週間に 1 回、計 9 回投与 された。初回手術より276日目の胸部単純 X 線検查にて、右中葉および後葉に腫瘤を認めたため、精査と治療を目的とし て日本動物高度医療センター名古屋を受診した。

一般身体検查、血液検查で異常所見は認められず、右肺腫瘤の進行度の評価を目的とした全身造影 Computed Tomography（以下、CT）検査を実施した。造影剤にはイオベリン注 300 （イオヘキソール注射薬、テバ製薬株式会社） $2 \mathrm{ml} /$ $\mathrm{kg}$ を用い、急速静脈内投与直後から撮像を開始した。CT 画像上で計測し、右中葉後部尾側端に $30 \times 26 \times 22 \mathrm{~mm}$ の nodule mass、右後葉に約 $9 \mathrm{~mm}$ 径の small nodule mass を認めたが、胸腔内リンパ節の腫脹は認めなかった（図1a，図1b)。右肺2 葉に nodule mass を認め、9 カ月前の肺腺癌の肺内転移が疑われたが、その他の肺葉には微小病変は認められなかった。今 後の治療方針として、経時的に右中葉および右後葉腫瘤の増大傾向を観察し、新病変が認められない場合には外科的切除 を検討することとした。経過観察期間中は紹介病院でカルボプラチンを $100 \mathrm{mg} / \mathrm{m}^{2} /$ を 2 週間に2回投与することとしたが、 第31病日の胸部単純 X 線検査で右肺腫瘤の増大が確認され、さらに第 32 病日には発咳の後に少量の喀血が認められ、第 45 病日に進行度の再評価を目的として胸部単純 $\mathrm{X}$ 線検查と胸部造影 $\mathrm{CT}$ 検查を実施した。右中葉の腫瘤は $38 \times 34 \times 24 \mathrm{~mm}$ 、右 後葉の腫瘤は約 $13 \mathrm{~mm}$ 径と増大していたが、胸胿内リンパ節腫脹は認められなかった (図 $2 \mathrm{a}$, 図 $2 \mathrm{~b}$ )。

右肺 $2 つ の$ 腫瘤は初回手術の肺内転移が疑われ、増大傾向を示しているが、他の肺葉に新たな病変の出現が無いこと、胸 腔内リンパ節の腫大が認められないことから、臨床症状の改善および根治の可能性を期待し、第53病日に右中葉抢よび右 後葉の外科的切除を行った。左横臥位に保定し、右第5-6肋間にて開胸した。腫瘍は右中葉および右後葉に限局しており、 周囲との癒着や癌性胸膜炎、胸水貯留、肺門リンパ節腫大などの所見は認められなかった（図 $3 \mathrm{a}$, 図 $3 \mathrm{~b}$ )。右中葉は肺門部 から $1 \mathrm{~cm}$ の部位で1号ナイロン糸を用いて肺動静脈・気管支を一括結紮した。合計 3 糸結紮を行い、腫韵側に鉗子をかけた 後に、十分なサージカルマージンを確保し右中葉を切除した。続いて、右後葉と副葉との葉間の間膜をバイポーラにて分 離し、右後葉肺門部から $1 \mathrm{~cm}$ の部位で1号ナイロン糸を用いて肺動静脈・気管支を一括結紮した。同様に、追加結紮を行 い、腫瘍側に鉗子をかけた後に十分なサージカルマージンを確保し右後葉を切除した。ついで胸腔内に生理食塩水を注入 し、用手にて陽圧換気を行い空気の漏れがないことを確認した。 $8 \mathrm{Fr}$ フィーディングチューブを胸脭チューブとして設置 した。完全に閉胸する前に肺虚脱の予防として陽圧換気を行い、肺を十分拡張させ、胸腔チューブより空気除去し定法通

1）日本動物高度医療センター 名古屋 †468-0003 愛知県名古屋市天白区鴻の巣1-602

2）ペットクリニックあおき $=470-0124$ 日進市浅田町平子4-314

3）日本動物高度医療センター 川崎＝213-0032 神奈川県川崎市高津区久地2-5-8

4）株式会社サップス／獣医外科病理センター％305-0857＼cjkstart茨城県つくば市羽成86-1

連絡責任者：古川敬之 日本動物高度医療センター 名古屋 T468-0003 愛知県名古屋市天白区鴻の巣1-602

電話：052-933-9901、FAX：052-800-1213 メールアドレス：takayuki.furukawa@jarmec.jp

受付日：2014年7月1日、採択日：2014年11月10日 


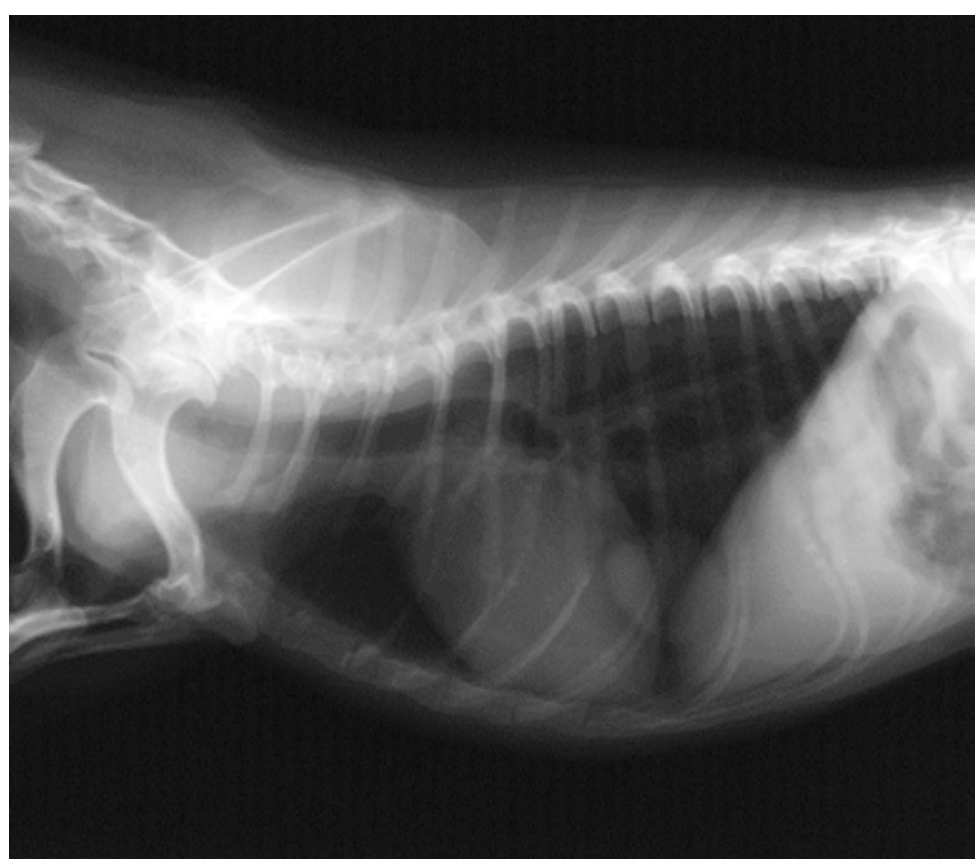

図1a. 第0病日 右側側臥位胸部単純 X 線像 右中葉に30×26mm の腫瘤、右後葉に約 $9 \mathrm{~mm}$ 径の結節を認めた。胸腔内リンパ節の腫脹は認めなかった。

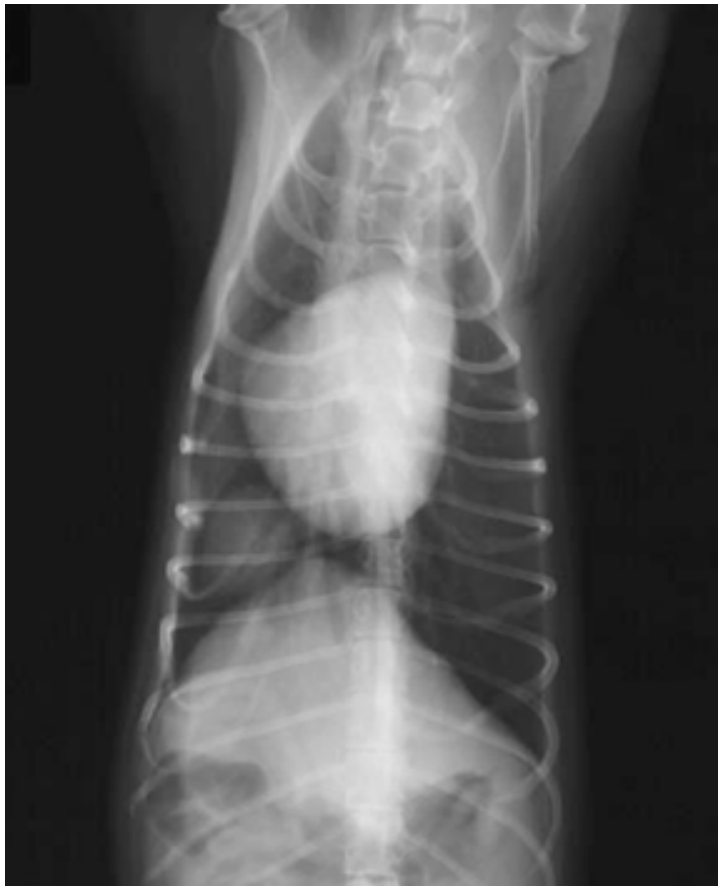

図1b. 第0病日＼cjkstart仰臥位胸部単純 X 線像

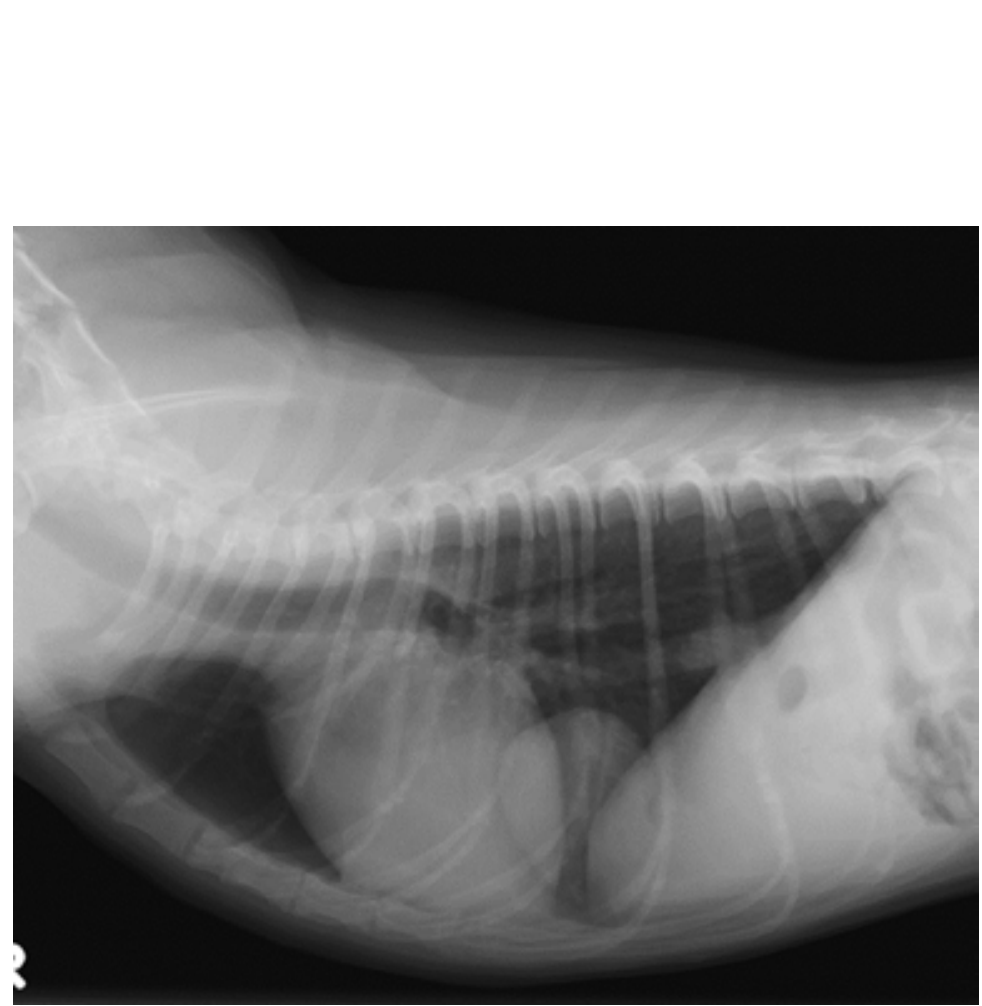

図2a. 第45病日 右側側臥位胸部単純 X 線像

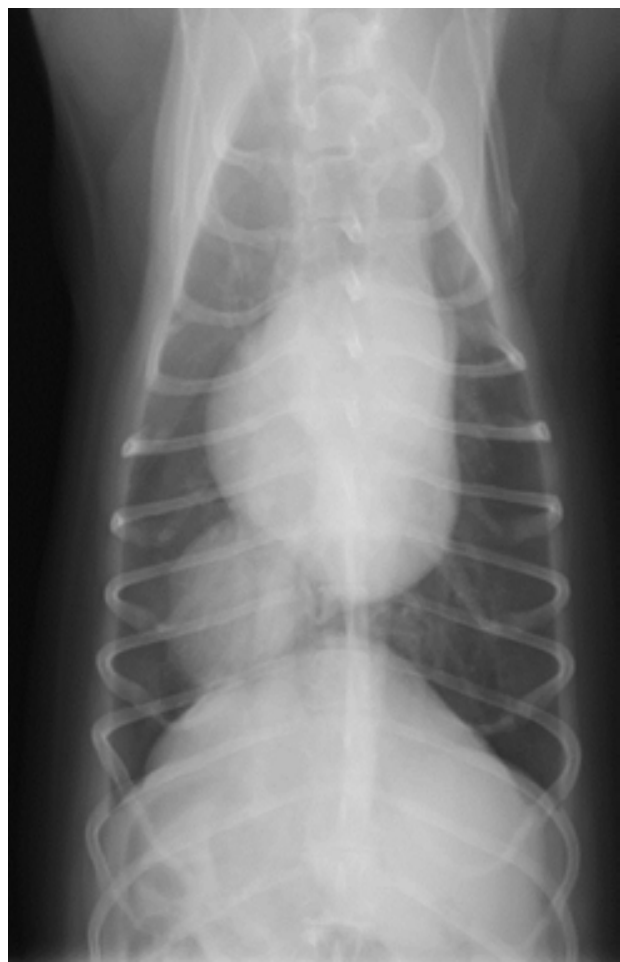

図2b. 第45病日 仰臥位胸部単純 X 線像 右中葉の腫瘤は $38 \times 34 \mathrm{~mm}$ 、右後葉の結節は約 $13 \mathrm{~mm}$ 径と増大していた。胸腔内リンパ節腫脹は認められなかった。

\section{り閉胸した。}

手術翌日および第57病日に一過性に気胸が認められたが定期的な抜気により改善した。右中葉および右後葉に認められ た腫瘤の病理組織学的検査結果は左肺葉腫瘤と同様に肺腺癌であった。腫瘍巣では、立方から円柱状あるいは類円形の腫 瘍細胞が腺腔形成性や管状に増殖する部位（図4a）、および類円形の腫瘍細胞がシート状や充実性に配列し増殖する部位 (図4b) が混在して認められた。円柱状の腫瘍細胞には質上縁に線毛様構造を有す細胞を認め、核は基底膜側へ偏在してい 


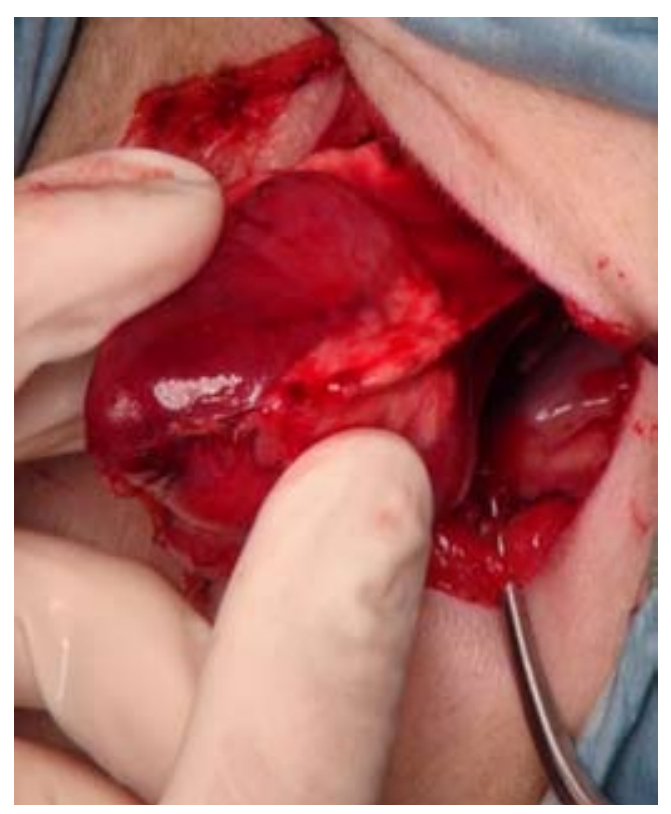

図3a． 第53病日 術中写真 右中葉

腫瘍は右中葉および後葉に限局しており、周囲との癒着や癌性胸膜炎、胸水貯留、肺門リンパ節腫大などの 所見は認められなかった。

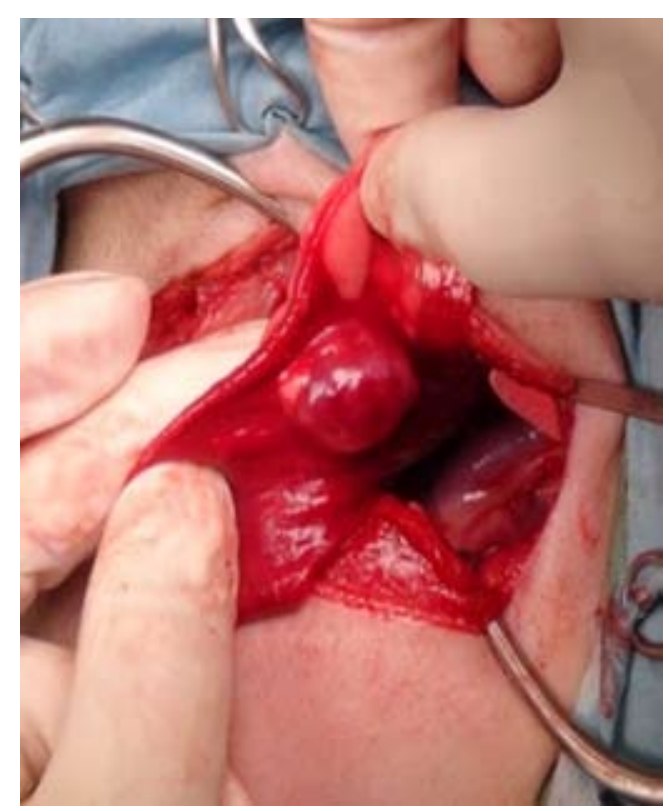

図3b. 第53病日 術中写真 右後葉

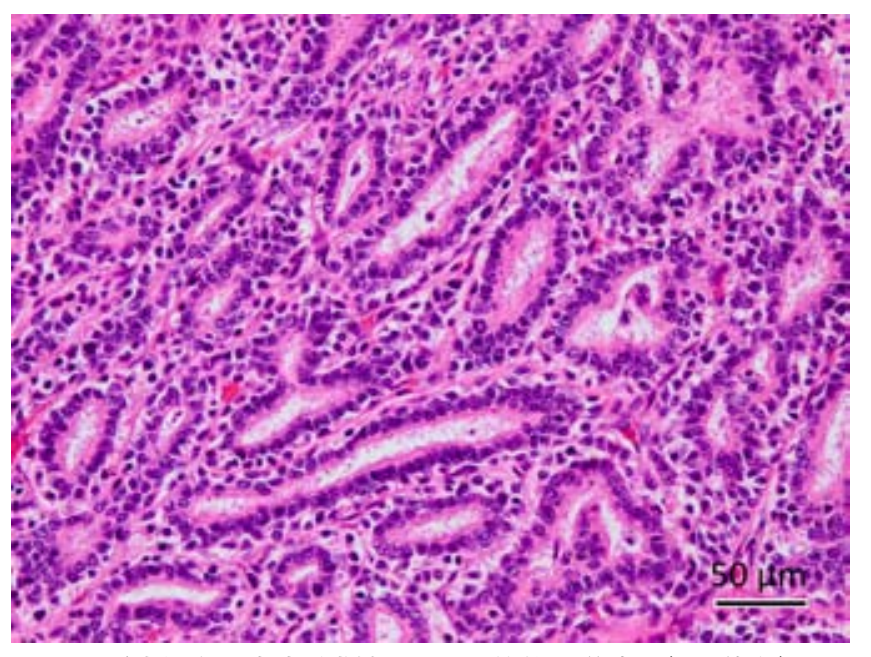

図4a. 腫瘍細胞が腺腔形成性あるいは管状に増殖 （HE 染色）

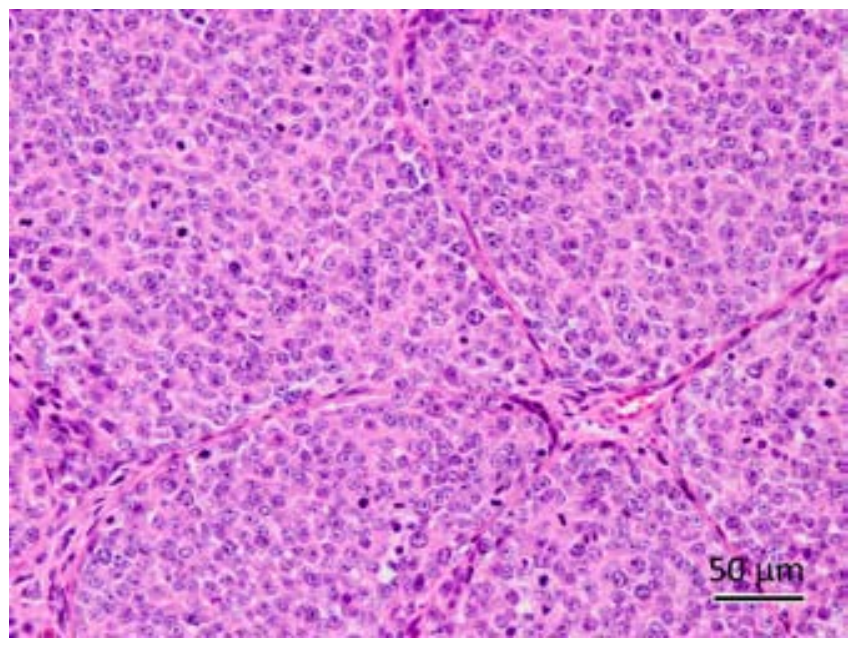

図4b. 腫瘍細胞がシート状あるいは充実性に増殖（HE 染色）

た。腫瘍細胞の異型性は高く、核分裂像が多数認められたが、検索範囲では脈管内浸潤は認められず、サージカルマージ ンには腫瘍細胞は認められなかった。また本例では、手術前の第21病日よりピロキシカム (バキソカプセル10、大正富山 医薬品株式会社）を $0.3 \mathrm{mg} / \mathrm{kg} / 3$ 日ごと、補助的化学療法として第74病日よりカルボプラチン（カルボプラチン注射薬、日 医工） $250 \mathrm{mg} / \mathrm{m}^{2} / 3$ 週で静脈内投与した。術後の定期検查として胸部単純 X 線検查で経過観察し、本論文投稿時に第726 病日が経過したが新病変の出現や胸胿内リンパ節の腫大は認められず良好な経過が得られている。

犬の原発性肺腫瘍の予後因子として、腫瘍のサイズ、TNM stage、リンパ節浸潤、診断時の臨床症状、術後肉眼的病変、 組織学的タイプ、肺葉全体への浸潤、組織学的グレードが挙げられる。しかし、これら様々なステージの原発性肺腫瘍に 対する術後の補助的化学療法の有効性についてはいまだ明らかではない。本例では、前回切除された左前葉前部の腫瘍サ イズは $3.0 \times 4.0 \times 2.5 \mathrm{~cm}$ と $100 \mathrm{~cm}^{3}$ 以下、組織学的に低分化型の腺癌でリンパ節腫大などは認められなかった。Ogilvie らは 原発性肺腫瘍の犬 210 頭について191頭で腫瘍の位置を特定しており、53.8\%は単一肺葉、37.1\%は複数の肺葉に認められる と報告している [5]。本例では化学療法中の術後検診で実施した単純 X 線検査で肺病変は認められなかったが、化学療法

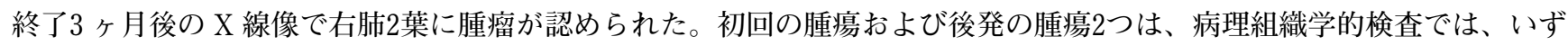
れも組織形態的に同一であり、後発の腫瘍は初回に発生した腫瘍の転移と考えられた。初回扎よび後発の各腫瘍のいずれ 
においても組織形態的にリンパ管や血管における腫瘍細胞浸潤は確認されなかったが、標本上で確認された腫瘍部位以外 において脈管内浸潤が存在した可能性は否定できない。一方、腫瘍の転移ではない場合、新たに発生した腫瘍（多発性） である可能性も考えられるが、多発性肺癌の定義は、(1)組織型が異なる場合、(2)組織型が同一であるが、離れた部位にあ り、a. 後発した腫瘍の発生まで2年以上の期間がある、b. 上皮内癌成分がある、c. 後発した腫瘍が他肺葉、他肺病変で、共

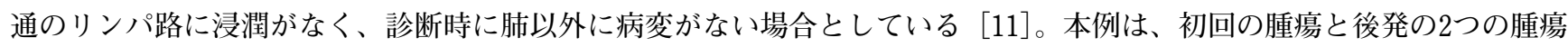
の細胞形態的な所見が同一であり、前述の定義の少なくとも(2) a. およびb.に合致しないことから、本例において多発性 に腫瘍が発生した可能性は考え難いと結論される。さらに、手術手技による問題の可能性について、初回の腫瘍が左肺に

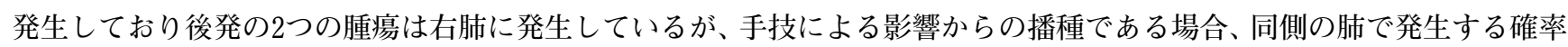
が高いと考えられる。左から右へ縦隔をまたいでの播種は考元難く、手術時の影響の可能性も除外されると考えられる。

Paoloni らは気管気管支リンパ節に転移の認められる原発性肺腫瘍の犬14例について CT と胸部単純 X 線検查結果を比 較検討し、気管気管支リンパ節転移の検出率は胸部単純 X 線検查の $57 \%$ に対し胸部 CT 検査では $93 \%$ と著しく高いと報告 している $[6]$ 。また肺転移が疑われる犬18頭では、CT 検査で描出された病変を単純 X 線検査で検出できたのはわずか $9 \%$

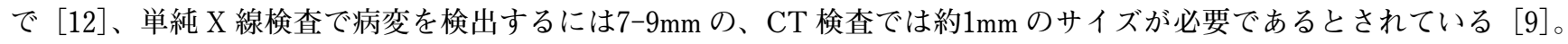
犬の原発性肺腫瘍の診断や術後の再発を早期に発見するためには、CT 検查を行うことが必要と考えられる。

犬の左肺打よび右肺容量はそれぞれ全容量の $42 \% 、 58 \%$ を占め、肺葉を $75 \%$ 以上切除すると死に至る。肺葉切除後は残 存肺の膨張や肺血流量増加などの代償により、既存の生理学的な拡大容量の増加や肺胞-毛細血管ネットワークのリモデリ ングが起こる $[10]$ 。健常な犬において、肺葉切除後に残存肺容量、肺活量、最大換気量は低下するが、残存肺容量は 3 ケ 月後には十分量にまで増加するとされている $[1]$ 。Koucaturk らは肺葉切除（12頭）および片側全肺葉切除（8頭）の犬に ついて術前-術後の心機能を評価し、心機能不全は肺外科手術後に共通した合併症で、とくに片側全肺葉切除で発現する完 全房室ブロックは死亡につながる可能性があると考察している $[4]$ 。また、片側全肺葉切除は肺葉切除と比較し、術後の 全身性炎症反応症候群スコアおよび肺高血圧リスクを上昇させると報告している。本例では、左前葉前部切除に加え、右 中葉打よび右後葉切除により全肺葉中約 50 \%を切除することとなったが、術後に全身性炎症性症候群や心電図異常、肺高 血圧などは認められなかった。拉そらくは、右中葉および右後葉切除が左前葉前部切除の約 9 ヶ月後であったため、この 期間中に前述した代償機構が構築されており、術後の合併症が発現しなかったものと推測される。

一方、Hifumi らは原発性肺癌の犬52頭、猫18頭で抗腫瘍薬に対する多剤耐性に関連する蛋白の発現を免疫組織学的に検 討し、 $\mathrm{P}$ 糖蛋白、多剤而性関連蛋白ならびに肺抵抗性関連蛋白がすべての肺腺癌腫瘍細胞に高頻度に発現していると報告 している [3]。またこの結果から、犬や猫の原発性肺癌は多剤抵抗性で、抗腫瘍薬による治療は困難と考えている。一方、 Poirier らは気管支肺胞癌7頭にビノレルビンを投与し、2頭に部分緩解を認めたと報告している $[7]$ 。今回、我々は術後の 補助的化学療法としてカルボプラチンを使用した。カルボプラチンは幹細胞減少性の骨䯣抑制を引き起こすが、右中葉打 よび右後葉切除手術後に計19回（累積投与量 $1268.25 \mathrm{mg}$ )、左前葉前部切除手術からでは計31回（累積投与量2037.75mg）投 与したが、長期投与による骨髄毒性は認められなかった。また、消化器毒性の発現なども認められず十分に許容すること ができた。原発性肺腫瘍や原発性肺腫瘍の肺内転移に対する補助的化学療法としてのカルボプラチンの有効性の検討につ いてはさらなる症例数の蓄積が必要であるが、本論文投稿時点にて第726病日（初回手術より1002病日）経過したが、新た な肺病変の出現は認められず現在も生存中である。本例では、原発性肺腫瘍切除後に胸腔内リンパ節の腫大を伴わない肺 内転移を疑う結節病変が出現したが、積極的な外科切除や術後補助的化学療法などによる集約的治療を実施することで良 好な経過が得ることができている。 


\section{参考文献}

[1 F ossum, T.W. (若尾義人，田中茂男，多川政弘監訳）（2008）：Small Animal Surgery. (日本語版)。3rd ed. 第29章下部呼吸器 系の外科 : 肺および胸壁., pp. 975-1007. Interzoo, 東京.

[2] Griffey, S.M., Kraegel, S.A., Madewell, B.R. (1998) : Rapid detection of K-ras gene mutations in canine lung cancer using single-strand conformational polymorphism analysis. Carcinogenesis. $19: 959-963$.

[ 3 ] Hifumi, T., Miyoshi. N., Kawaguchi. H., Nomura. K., Yasuda. N. (2010) : Immunohistochemical detection of proteins associated with multidrugresistance to anti-cancer drugs in canine and feline primary cartinoma. J. Vet. Med. Sci. 72 : 665-668.

[4] Kocaturk, M., Salci, H., Yilmaz, Z., Bayram, A. S., Koch, J. (2010) : Pre-and post-operative cardiac evaluation of dogs undergoing lobectomy and pneumonectomy. J. Vet. Sci. 11 (3) : 257-264.

[ 5 ] Ogilvie, G.K., Haschek, W.M., Withlow, S.J., Richardson, R.C., Harver, H.J., Henderson, R.A., Fowler, J.d., Norris, A.M., Tomlinson, j., McCaw, D. (1989) : Classification of primary lung tumors in dogs : 210 cases (1975-1985). J. Am. Vet. Med. Assoc. $195: 106-108$.

[6] Paoloni, M.C., Adams, W.M., Dubielzig, R.R., Kurzman, I., Vail, D.M., Hardie, R.J. (2006) : Comparison of results of computed tomography and radiography with histopathologic findings in tracheobronchial lymph nodes in dogs with primary lung tumors : 14 cases (1999-2002). J. Am. Vet. Med. Assoc. $228: 1718-1722$.

[ 7 ] Poirier, V.J., Burgess, K.E., Adams, W.M., Vail, D.M. (2004) : Toxicity, Dosage, and Efficacy of Vinorelbine (Navelbine) in dogs with Spontanous Neoplasia. J. Vet. Intern. Med. $18: 536-539$.

[8] Rebhun, R.B., Culp, W.T.N. (2013) : Tumors of the Respiratory system. In: Small Animal Clinical Oncology, 5th ed. (Withrow, S. J. and Vail, D. M. and Page, R. L. eds.), pp. 453-462. Saunders, Missouri.

[ 9 ] Marolf, A.J., Gibbons, D.S., Podell, B.K., Parf, R.D. (2011) :Computed tomographic appearance of primary lung tumors in dogs. Vet. Radiol. Ultrasound. 52 : 168-172.

[10] Martano, M., Boston, S., Morello, E., Withrow, S.J. (2013) : Respiratory Tract and Thorax. In : Veterinary Surgical Oncology, (Kudnig, S.T. and Seguin, B. eds), pp. 273-328. Wiley-Blackwell, Oxford.

[11] Martini, N., Melamed, M.R. (1975) : Multiple primary lung cancers. J. Thorac. Cardiovasc. Surg. 70 : 606-612.

[12] Nemanic, S., London, C.A., Wisner, E.R. (2006) : Comparison of thoracic radiographs and single breath-hold helical CT for detection of pulmonary nodules in dogs with metastatic neoplasia. J. Vet. Intern. Med. 20 : 508-515. 